\title{
Customer Relationship Management as a Tool for Improving Customer Loyalty in the Banking Industry: An Empirical Study of Guaranty Trust Bank PLC Situated within the Central Business District, FCT Abuja, Nigeria
}

\author{
Yakubu Yari Kate Dazagbyilo, Shuiping Shang, Obodo Chidiebube Emmanuel, \\ Kalissa Fatoumata Kir
}

School of Economics and Management, Anhui University of Science and Technology, Huainan, China

Email: Yakubu.kik555@gmail.com, zhsp310@163.com, chidiebubeobodo1523@gmail.com, kfatoumatakir25@gmail.com

How to cite this paper: Dazagbyilo, Y. Y. K., Shang, S. P., Emmanuel, O. C., \& Kir, K. F. (2021). Customer Relationship Management as a Tool for Improving Customer Loyalty in the Banking Industry: An Empirical Study of Guaranty Trust Bank PLC Situated within the Central Business District, FCT Abuja, Nigeria. Open Journal of Business and Management, 9, 2299-2311. https://doi.org/10.4236/ojbm.2021.95124

Received: August 5, 2021

Accepted: September 11, 2021

Published: September 14, 2021

Copyright $\odot 2021$ by author(s) and Scientific Research Publishing Inc. This work is licensed under the Creative Commons Attribution International License (CC BY 4.0).

http://creativecommons.org/licenses/by/4.0/

\begin{abstract}
Because of the fierce competition in the banking business, it is critical for banks to develop and maintain strong client relationships in order to achieve customer satisfaction and loyalty. As a result, in the banking industry, Customer Relationship Management (CRM) has become extremely important. As a result, the focus of this research was on CRM as a tool for increasing customer loyalty and happiness. The participants in this study are GTBank Plc clients in the FCT Abuja's core business area. A total of 150 people were chosen at random, and data was collected via questionnaires that were self-administered by a researcher. The research revealed an important connection between customer happiness and loyalty and CRM proxies (service quality, employee conduct, customer data base, solving customer problems, physical environment and social network engagement). It was suggested that banks perform special training programs for their whole operations personnel in order to interact with clients efficiently and effectively by identifying key CRM tools in the financial business.
\end{abstract}

Keywords

CRM, Services Marketing, Banking Industry, Customer Satisfaction, Abuja

\section{Introduction}

Due to recent changes in the business climate, such as increased customer churn, 
decreased brand loyalty, and decreased profitability, firms across all industries have realized that having strong customer relationships is one of the most valuable assets they can have. Companies are changing from product-centric and brand-centric marketing tactics to a customer-centric approach as a result of these shifts (Tetteh, 2008). Fitzgibbon and White (2005) was of the view that, many organizations' management approaches have shifted from focusing solely on gaining new consumers to understanding the importance of retaining existing customers and the necessity to foster loyalty among these customers. Companies have experienced and continue to confront issues managing relationships with customers since they have varying requirements and participate in varying transactions. To address these issues, most, though not all, businesses are now actively engaged in customer relationship management. Customer relationship management (CRM) entails forging, maintaining, and improving strong bonds with customers and stakeholders (Kotler \& Keller, 2009). Customer relationship management's purpose is to provide long-term value to customers, and long-term customer happiness is the yardstick by which success is measured. Customer Relationship Management necessitates that all divisions in a company work together as a team with marketing to service customers, and thus necessitates the development of connections at several levels, resulting in high customer loyalty (London Centre of Marketing, 2008).

\subsection{Statement of the Problem}

Inside the banking business, being in close contact with customers is critical in order to create excellent relationships and gain customer loyalty in an ever-changing competitive climate. As a response of this evolution, the key elements of customer relationship management that can lead to client loyalty have become a crucial issue for financial institutions, particularly given the fierce competition among industry competitors.

Customers are critical to a bank's success, and how these components are managed influences the bank's efficacy and efficiency, as well as its overall performance. This is because most banks provide the same set of services to their customers, and the only way to stand out and achieve a market competitive advantage over other banks is to treat consumers like kings. As the Nigerian banking business expands, so does the level of rivalry among industry participants. One may deduce that the level of competitiveness in the Nigerian banking business has a positive linear relationship with its growth. As a result, all market actors appear to be business monsters who go to great lengths to win client loyalty. As a result, the focus of this research is on the influence of customer relationship management as a strategy for increasing customer loyalty.

\subsection{Objective of the Study}

The primary goal of this research is to evaluate and analyze the impact of customer relationship management as a strategy for increasing customer loyalty. 
The study's precise objective, on the other hand, is:

To assesses basic steps of customer relationship management that can achieve loyalty of customers at the GTBank branch within the central business district, FCT Abuja.

To show how the types of customer relationship management (Operational, Analytical and Collaborative) works to deliver their functions successfully within organisations.

\subsection{Analytical Framework}

Under this section, the researcher tends to look for how customer relationship management brings customer loyalty in the guaranty trust bank plc situated within the central business district, FCT Abuja-Nigeria. This study depicts the relationship that exists among Customer relationship and customer loyalty in the guaranty trust bank plc situated within the central business district, FCT Abuja-Nigeria. The researcher based on some variables that explains the customer relationship management. The relationships among these variables are presented in visual format (Figure 1).

\subsection{Research Hypothesis}

This research formulates the following assumptions:

$\mathrm{H}_{0}$-Statistically, Customer relationship management has no impact on customers' loyalty and satisfaction at GTBank branch situated within the central business district, FCT Abuja.

$\mathrm{H}_{1}$-Statistically, Customer relationship management has an impact on customers' loyalty and satisfaction at GTBank branch situated within the central business district, FCT Abuja.

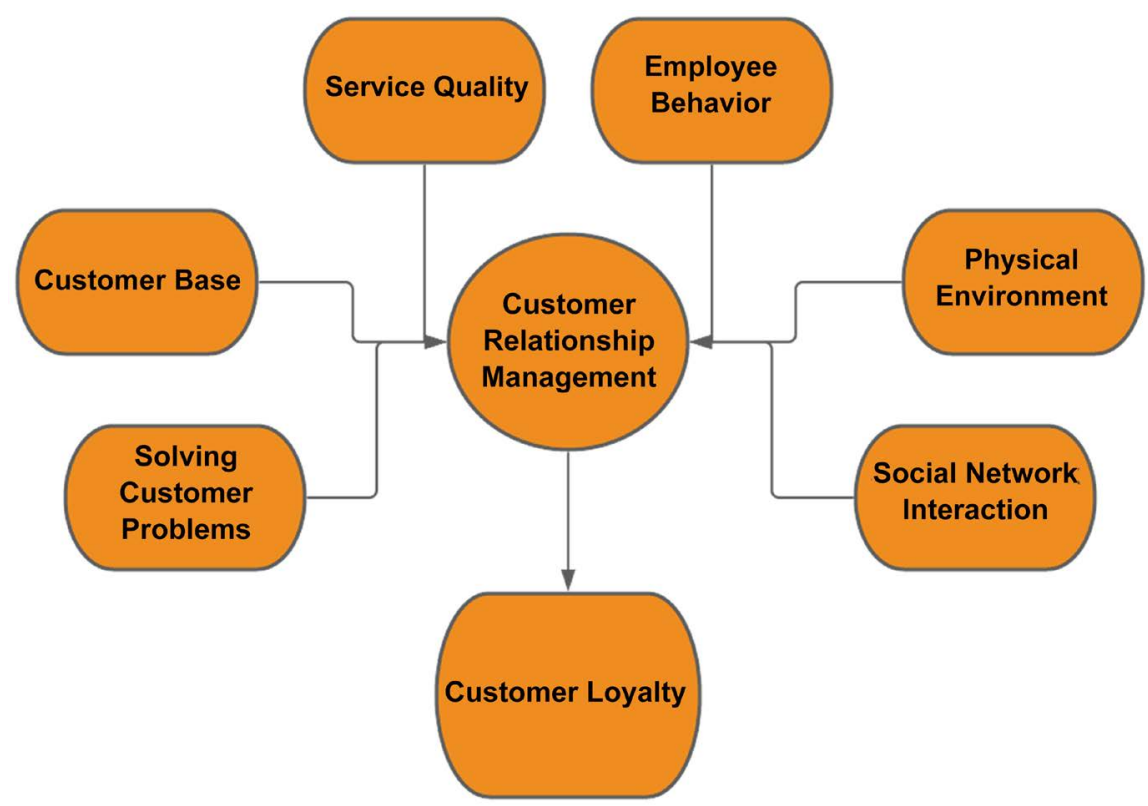

Figure 1. Conceptual framework. 


\section{Review of Related Literature}

Customers are not always what they are logically expected to be, therefore understanding the notion of Customer Relationship Management requires an understanding of customer behavior (Greenberg, 2009). Customer relationship management (CRM) is a business technique for deeper understanding, expecting, and managing the demands of existing and potential customers. It is a multi-stage journey in which an organization strives to better manage its business around customer behavior through strategy, process, organizational, and technical change. The ultimate goal is to find, keep, and expand lucrative clients. It necessitates a laser-like focus on the service characteristics that provide value to clients and foster loyalty. Customer relationship management enables firms to build effective targeting and inquiry management systems, resulting in a considerable increase in new business growth (Adiele \& Gabriel, 2013). According to Kubil \& Doku (2010), there are a variety of advantages to strong customer relationship management, including:

1) It enables for gross sales chances, resulting in lower client spending over time. The assurance of gross sales; trying to sell extra items and services to existing customers; and the overall belief that customers would buy more in the long run if they are content with the company, its product, and services is the attraction of building customer relationships for several organizations.

2) Building relations with clients deters competitors from obtaining them since pleased and maintained customers are less receptive to participants' appeal, implying that a pleased customer is immune to competition's draw.

3) The costs of sales, promotion, and setup are amortized over a longer customer life cycle. In keeping with this, there is an initial set-up cost connected with obtaining new clients that can be recovered over a period of time. Client money matters increase over time, which is why it's critical to assess the potential time period lifetime revenue from a customer relationship from a lifetime value standpoint.

The benefits of customer relationship management, according to Richards \& Jones (2008), include better potential to identify lucrative customers, compatible packages across networks, enhanced sales power competence and success, personalized advertising campaigns, goods and services of high quality, improved pricing, and enhanced customer care cost effectiveness. Customers establish logic of closeness and a social bond with their able service suppliers as a result of customer relationship management, making them less inclined to change even if they study about a challenger who may provide a high quality service, product and lower prices. According to Chen \& Popovich (2003), other advantages of customer relationship management comprise improving the organization's ability to acquire and keep customers, as well as maximizing the lifespan value of the customers.

According to Kotler and Armstrong (2011), the very first way to accomplish business goals is to elicit the following inquiries: Who is really the customer? 
What does he purchase? What is the best way to contact him? Ways his allegiance be guaranteed and maintained? Clearly, the responses to the preceding inquiries can only be obtained if a company implements a policy of remaining close to its clients by way of effective customer relationship management. According to Brian (2011), marketing strategy imparts that in order for any firm to flourish, the client must be at the centre of all organizational events. As a result, the idioms "customers are kings" and "customers are always right" are derived from this idea. Alis, Karakurt and Melli (2000) emphasized the importance of customers, stating that the customer is at the center of all marketing efforts.

According to study by Formant (2009), a client is "one who, motivated by self-centredness, has the option of heading towards you to purchase your product and service or going to a different place." Likewise, Dyché (2002) noted that once recognising the strength of clients, it is helpful to recollect that continuous firm is the strength of selling. It contributes to the business's income and predictability; enterprises rely on their consumers, and if they do not build customer happiness and loyalty, they risk losing them. The organization would not exist without consumers; the organization's mission is to meet the requirements of customers; and customers enable the achievement of business objectives. Customers today are notoriously tough to satisfy. They are cleverer, conscious about the price, more challenging, and less pardoning, and they're being courted by rivals with equivalent or greater deals. As a result, the objective is not to produce satisfied customers; this is something that many competitors can achieve. The goal is to create loyalty of customers (Kotler \& Armstrong, 2011).

\subsection{Types of Customer Relationship Management}

Various scholars have raised differing opinions on which types of CRM considerations are the most effective. Reynolds (2002), for example, defined three forms of CRM in her book: operational, analytical, and collaborative CRM. These three distinct categories were also discussed in a recent study by (Rollins \& Halinen, 2005). Similarly, Dyché (2002: p. 13) stressed operational and analytical CRM in his work. However, Buttle (2009: p. 4) recently proposed strategic CRM as a fourth form of CRM in his book. In particular, these various types of CRM are essential since they all have the same goal in mind: to successfully deliver CRM within organizations. As a result, we present and discuss all four major types of CRM in this section.

\subsubsection{Operational CRM}

An operational CRM is also known as front office CRM, according to Dyché (2002: p. 13). It refers to the areas where direct client contact takes place, sometimes referred to as touch points. A touch point can be an inbound (e.g., a call to a company's customer service hotline) or outbound (e.g., a visit to a company's website) (e.g. an in-person sales call or an email promotion to customers). To put it another way, the operational CRM is utilized to collect customer information. The operational CRM also facilitates and enhances customer communica- 
tions, but this does not always imply that service is optimized. Because a financial services customer checks his or her balance on a webpage does not prove that he or she prefers to conduct his or her transaction in a branch. The various levels of operational CRM are depicted in Figure 2.

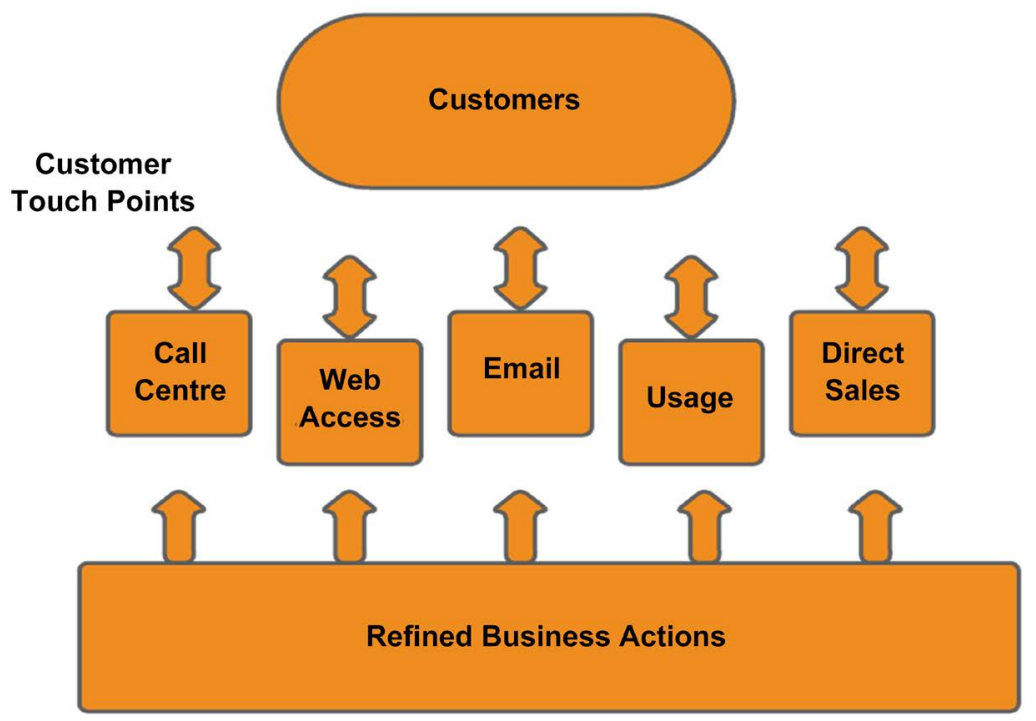

Figure 2. Operational CRM: touching the customer (Source: Dyché, 2002: p. 13).

\subsubsection{Analytical CRM}

A back office CRM is often referred as an analytical CRM. It entails figuring out what happened in the front office with the clients. Technology (to aggregate and handle mountains of customer data to assist analysis) and new business procedures are required for analytical CRM (to refine customer-facing practices to increase loyalty and profitability). Following demand from analysts and industry experts, most CRM companies today are developing analytical CRM capabilities or forming partnerships with business intelligence (BI) providers to implement analysis into their products (Dyché, 2002: p. 13). Figure 3 depicts ways in which

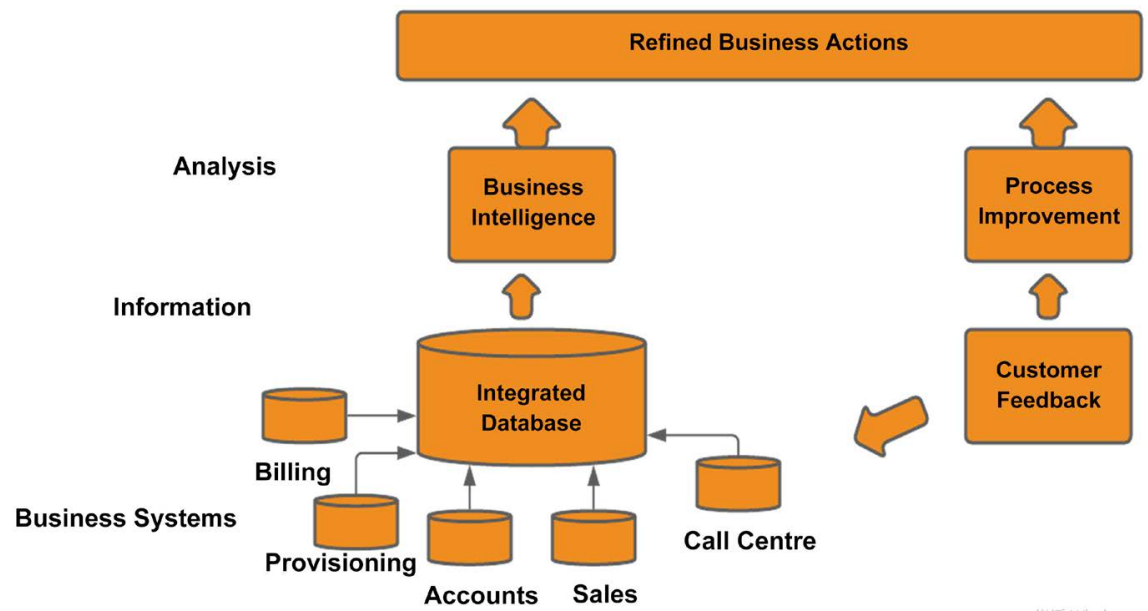

Figure 3. Analytical CRM: understanding the customer (Dyché, 2002). 
data and procedures work together to improve business decisions. The refined-business-actions component of the Customers Call Centre Web Access E-mail Usage Direct Sales Refined Business Actions Customer Touch points 42 puzzle is the most complex to put in place, according to Dyché (2002: p. 13). The more missing elements there are, the more difficult it is to put together a meaningful CRM picture. To put it another way, if improved client loyalty is the key, then integration is the entrance.

\subsubsection{Collaborative CRM}

"Collaborative CRM is a CRM technique in which many departments within a company, such as sales, technical support, and marketing, share any information gathered from customer interactions" (Chai, 2007). Consumer input from a technical support session, for example, could advise marketing employees about items and services that the customer might be interested in. The goal of this collaboration is to improve customer service quality in order to boost customer happiness and loyalty. "A collaborative CRM system is primarily used for constructing online groups, establishing business-to-business touchpoints, and personalizing services," is according to Rollins and Halinen (2005) and Adebanjo (2003).

\subsection{Basic Steps in Customer Relationship Management}

Customer relationship management, according to Kotler (1999), is a talent that allows businesses to provide great real-time client care by building a relationship with each value-added customer through the effective use of individual account information. According to Peppers and Rogers (1995), customer relationship management consists of four steps.

1) Get as much information on your clients as possible, including demographics, psychographics, habits, and preferences.

2) Distinguish between them (for example, most profitable and least profitable).

3) Have a conversation with your clients (making this interaction cost effective using customization where if necessary).

4) Use bulk customization or individual tailoring to personalize your offerings to each customer's demands.

A company's ability to learn and understand its clients improves as it progresses through these four stages, allowing it to give more relevant and customized solutions. As a result, the true goal of association/customer relationship management marketing is to create a "study connection". Individual clients impart the firm about their preferences and needs via learning relationships. The more clients teach the firm, the success it gets at giving precisely what they need, making it harder for a challenger to draw them off (Peppers \& Rogers, 1995). Companies can gain profits on their investment from customer relationship management by supporting client loyalty and engendering their relocation to 
upmarket, innovative, and bigger range of product and service through effective methods and campaign management.

The customer relationship management systems are designed to help businesses save money by making client recruitment more cost-effective, lowering sales costs, enhancing retention of customers and loyalty, and decreasing the need for regular and costly calls to interest new consumers. Customer relationship management systems also lower the expenses of marketing to low-profit customers by allowing organizations to identify and focus on their high-profit clients, allowing them to transform low-value customers into higher-value ones. Customer attention has the overall benefit of retaining loyal customers and increasing share of wallet through cross-selling and up-selling. According to research, there is a substantial link between client retention and corporate profitability (Kalu, 2005).

\section{Methodology}

This research study requires quantitative analysis because of the phenomena under study. Due to this fact, the researcher will employ the survey research method to analyze the data for the research. This research will use first-hand information obtained by a researcher through structured questionnaires to gather the data needed to answer our research questions. The population of this study consists of customers of GTBank PLC situated within the central business district, FCT Abuja. Out of our total population banking with GTBank in the selected branch, 150 were selected randomly based on a simple random sampling technique of Gall and Borg (2002). Since the questionnaire was designed in a Likert type format of Strongly Agreed (SA), Agreed (A), Not Sure (NS), Disagreed (D), and Strongly Disagreed (SD), the researcher will use Frequency and Percentages to analyze the demographic variables, while the construct of questions on customer relationship management and customer loyalty will be analyzed with the Weighted mean (Wm). The formula for the analysis, as well as the assessment weights are shown below.

\section{Assessment Weights:}

Strongly Agreed (SA) is worth 5 points; Agreed (A) is worth 4 points; Not Sure (NS) is worth 3 points; Disagreed (D) is worth 2 points; and Strongly Disagreed (SD) is worth 1 point.

The following is the formula for this analytical tool:

$$
\mathrm{Wm}=(\mathrm{NOR} \times \mathrm{EW}) / \mathrm{TSSWm}=(\mathrm{NOR} \times \mathrm{EW}) \mathrm{Wm}=(\mathrm{NOR} \times \mathrm{EW}) \mathrm{W}
$$

where $\mathrm{Wm}$ is the weighted mean, NOR denotes the number of replies for each option, EW denotes each weight, and TSS denotes the total sample size.

The Average Weighted Mean (AWm) Value will be computed in order to evaluate our hypothesis. The following is the formula for this statistical tool:

$$
\left\{\mathrm{AWm}=\sum\left(\mathrm{Wm}^{*}\right) / n\right\}
$$


where:

$\mathrm{Wm}^{*}=$ Weighted Mean Values; $n=$ Number of Values; $\mathrm{AWm}=$ Average Weighted Mean

Decision Rule 1: If the computed Wm values are greater than or equal to 2.50 , we conclude there is significant effect on the hypothesis. However, if the computed Wm values are less than 2.50, we conclude that there is no effect on the hypothesis.

Decision Rule 2: If AWm value is greater than or equal to 2.50, we accept our alternate hypothesis $\left(\mathrm{H}_{1}\right)$ and we reject our null hypothesis $\left(\mathrm{H}_{0}\right)$. On the contrary, when the AWm value is less than 2.50 we reject our alternate hypothesis $\left(\mathrm{H}_{1}\right)$ and we accept our null hypothesis $\left(\mathrm{H}_{0}\right)$

\section{Research Model:}

\begin{tabular}{cc} 
Customer Relationship Management (Explanatory Variable) & $\begin{array}{c}\text { Customer Loyalty } \\
\text { (Dependent Variable) }\end{array}$ \\
Behaviour of Employees & \\
Customer Database & $\begin{array}{c}\text { Customer Satisfaction \& } \\
\text { Loyalty }\end{array}$ \\
Relationship Through Solving Customer Problems & \\
Shysical Environment & \\
\hline
\end{tabular}

\section{Findings and Discussions}

In Table 1, the respondents were given 150 questionnaires, of which 135 were returned to the researcher. The surveys that were retrieved had a 90 percent return rate. However, 15 of the retrieved surveys were incomplete and could not be used to analyze the respondents' responses. As a result, the responses are analyzed using an 80 percent accurate response rate. Considering the demographic profile of the respondents, 71 respondents about (42.5\%) of the respondents were men while the rest of the 49 respondents $(40.83 \%)$ were women. Most of the respondents that were gotten were between the ages of 25 - 45 years amounting to $72.5 \%$. In terms of qualification, $47.5 \%$ have a bachelor degree while $32.5 \%$ had no degree. Majority of the respondents about $65.4 \%$ work in the private sector whiles $14.6 \%$ works in the public sector. Finally $57.8 \%$ of the customers have banked with GTBank for up to 6 - 10 years period whiles $22.2 \%$ have worked with the bank for 11 years upwards.

In determining the effect of CRM on client loyalty in a bank, the weighted mean values is calculated and illustrated below.

Table 2 shows the frequency of responses from the respondents based on the questionnaires using the Likert scale of strongly agree, agree, not agree, disagree and strongly disagree while Table 3 presents the computation of the weighted mean values of each option to our research questions. The results from our 
Table 1. Background information of respondents.

\begin{tabular}{ccc}
\hline Variable & Sub-scale & $\begin{array}{c}\text { Frequency } \\
\%\end{array}$ \\
\hline Gender & Male & $71(47.4 \%)$ \\
& Female & $49(32.6 \%)$ \\
Age & $24-45$ years & $72.5 \%$ \\
Qualification & Bachelor Degree & $47.5 \%$ \\
& No Degree & $32.5 \%$ \\
Place of Work & Private sector & $65.4 \%$ \\
& Public Sector & $14.6 \%$ \\
Customer period & 6 - 10 years & $57.8 \%$ \\
& 11 years \& above & $22.2 \%$ \\
\hline
\end{tabular}

Table 2. Customer responses.

\begin{tabular}{|c|c|c|c|c|c|c|c|}
\hline S/N & Proxies for CRM & SA & A & NS & $\mathrm{D}$ & SD & Total \\
\hline 1 & Service Quality & 51 & 43 & 14 & 7 & 5 & 120 \\
\hline 2 & Behaviour of Employees & 25 & 59 & 13 & 14 & 9 & 120 \\
\hline 3 & Customer Database & 45 & 28 & 12 & 16 & 19 & 120 \\
\hline 4 & Relationship through Solving Customer Problems & 17 & 57 & 10 & 23 & 13 & 120 \\
\hline 5 & Physical Environment & 32 & 27 & 3 & 27 & 31 & 120 \\
\hline 6 & Social Network Interaction & 23 & 18 & 13 & 37 & 29 & 120 \\
\hline
\end{tabular}

Source: Field Survey.

Table 3. Computation of weighted mean (Wm).

\begin{tabular}{|c|c|c|c|c|c|c|c|}
\hline \multirow[b]{2}{*}{ S/N } & \multicolumn{5}{|c|}{$(\mathrm{NOR} \times \mathrm{EW})$} & \multirow{2}{*}{$\frac{\text { Total }}{\Sigma(\text { NOR } \times E W)}$} & \multirow{2}{*}{$\frac{\underline{\mathrm{Wm}}}{\mathrm{\Sigma}(\mathrm{NOR} \times \mathrm{EW})} \frac{\mathrm{TSS}}{}$} \\
\hline & $\begin{array}{l}\text { SA } \\
\text { (5) }\end{array}$ & $\begin{array}{c}\text { A } \\
(4)\end{array}$ & $\begin{array}{l}\text { NS } \\
\text { (3) }\end{array}$ & $\begin{array}{l}\mathrm{D} \\
(2)\end{array}$ & $\begin{array}{l}\text { SD } \\
\text { (1) }\end{array}$ & & \\
\hline 1 & 255 & 172 & 42 & 14 & 5 & 488 & 4.07 \\
\hline 2 & 125 & 236 & 39 & 28 & 9 & 437 & 3.64 \\
\hline 3 & 225 & 112 & 36 & 32 & 19 & 424 & 3.53 \\
\hline 4 & 85 & 228 & 30 & 46 & 13 & 402 & 3.35 \\
\hline 5 & 160 & 108 & 9 & 54 & 31 & 362 & 3.02 \\
\hline 6 & 115 & 72 & 39 & 74 & 29 & 329 & 2.74 \\
\hline
\end{tabular}

Source: Researcher's Computation.

calculations shows that all the proxies of CRM enlisted serve as strong tools for customer loyalty because they have high Weighted Mean values of 4.07, 3.64, $3.53,3.35,3.02$, and 2.74 respectively. This means that these CRM tools are highly effective in creating customer satisfaction and loyalty for the bank. This result further tells us that most of the respondents (customers) believe that the 
Table 4. Weighted mean test of significance.

\begin{tabular}{lccc}
\hline \multicolumn{3}{c}{ Test of Hypothesis } \\
\hline & $\left(\mathrm{Wm}^{*}\right)$ Weighted Mean Values & $\Sigma\left(\mathrm{Wm}^{*}\right)$ & $\boldsymbol{\Sigma}\left(\mathrm{Wm}^{*}\right) / \boldsymbol{n}$ \\
\hline Proxies for CRM & $4.07,3.64,3.53,3.35,3.02$, and 2.74 & 20.35 & 3.39 \\
\hline
\end{tabular}

Source: Researchers Computation.

most effective CRM tool used by the bank is the "service quality" that they offer. On the other hand, the least effective tool is "social network interaction".

Table 4 shows that there is a positive Average Weighted Mean (AWm) value for our hypothesis. This signifies that CRM tools as stated in Table 1 are highly effective or statistically significant in creating customer loyalty and satisfaction. As a result, we can accept our alternative hypothesis $\left(\mathrm{H}_{1}\right)$ because AWm value is 3.39 which is more than 2.30 while rejecting the null hypothesis $\left(\mathrm{H}_{0}\right)$, resulting in the conclusion that, customer relationship management as significant impact on customers' loyalty and satisfaction at GTBank branch situated within the central business district, FCT Abuja.

\section{Conclusion and Recommendation}

Customer Relationship Management (CRM) is a precise strategic and influential tool and all the banks should consider implementing the CRM practices to enhance efficiency and effectiveness in order to retain customer and provide satisfaction. This paper is a brief review of how the relation that exists between CRM and the satisfaction of customer is achieved whilst retaining loyal customers. There are various bank implementing CRM practices which the bank can always implement, although only a few was used in this study. Banks must recognize the demand and need of their customers and make the CRM policies as a vital practice in Banks. Based on the customer's perspective, it was very clear that the overall service provided by GT bank is highly effective and efficient in creating customer loyalty, but there is always room for improvement because the banking market is so competitive, and banks must always learn to deliver extra value added services that are designed based on their customers' needs and wishes. Financial institutions should prioritize CRM as a marketing management tool in order to achieve a competitive advantage in the market by increasing customer satisfaction. With respect to the above discussions and findings, the following measures are recommended:

Banks should conduct special training programs for its entire operations staff to work or function efficiently and effectively.

Banking executives should improve the process and processes for directly and quickly resolving customer complaints and difficulties, since this can improve CRM and customer satisfaction and loyalty.

Exceptional care must be given by the management of the bank to its physical environment and technical structures, because they also have direct relationship 
with customer satisfaction and loyalty.

\section{Conflicts of Interest}

The authors have declared no conflict of interest in the publication of this article.

\section{References}

Adebanjo, D. (2003). Classifying and Selecting e-CRM Applications: An Analysis Based Proposal. Management Decision, 41, 570-577. https://doi.org/10.1108/00251740310491517

Adiele, K., \& Gabriel, J. (2013). Customer Relationship Management and Bank Performance in Nigeria: An Empirical Validation Study. International Journal of Science and Research, 2, 416-422.

Alis, O. F., Karakurt, E., \& Melli, P. (2000). Data Mining for Database Marketing at Garanti Bank, Proceeding of the International Seminar "Data Mining 2000". WIT Publications.

Brian, T (2011). The Marketing Concept: Profitability, the Key Measure of Success in Marketing.

Buttle, F. (2009). Customer Relationship Management: Concepts and Technologies (2nd ed.). Elsevier Ltd.

Chai, W. (2007). CRM (Customer Relationship Management). http://searchcrm.techtarget.com/sDefinition/0,sid11 gci939078,00.html

Chen, I. J., \& Popovich, K. (2003). Understanding Customer Relationship Management (CRM); People, Process and Technology. Business Process Management Journal, 9, 672-688. https://doi.org/10.1108/14637150310496758

Dyché, J. (2002). The CRM Handbook, a Business Guide to Customer Relationship Management. Addison-Wesley.

Fitzgibbon, C., \& White, L. (2005). The Role of Attitudinal Loyalty in the Development of Customer Relationship Management Strategy within Service Firms. Journal of Financial Services Marketing, 9, 214-230. https://doi.org/10.1057/palgrave.fsm.4770155

Formant, C. (2009). Customer Acquisition and CRM: A Financial Services Perspective. In S. A. Brown (Ed.), Customer Relationship Management: A Strategic Imperative in the World of E-Business. John Wiley and Sons.

Gall, M. D., \& Borg, W. R. (2002). Educational Research: An Introduction. Longman.

Greenberg, P. (2009). CRM at the Speed of Light, Capturing and Keeping in Internet Real Time. McGraw-Hill Ltd.

Kalu, F. O. (2005). Marketing Management. Pen Paper Publishers Aba.

Kotler, P. (1999). Principles of Marketing (8th ed.). Prentice Hall, Inc.

Kotler, P., \& Armstrong, G. (2011). Principles of Marketing (14th ed.). Prentice Hall.

Kotler, P., \& Keller, K. (2009). Marketing Management (14th ed.). Pearson International Edition.

Kubil, B., \& Doku, A. (2010). Towards a Successful Customer Relationship Management: A Conceptual Frame Work. African Journal of Marketing Management, 2, 37-43.

London Centre of Marketing (2008). Principles of Marketing Module. LCM Press.

Peppers, D., \& Rogers, M. (1995). A New Marketing Paradigm. Planning Review, 23, 
14-18. https://doi.org/10.1108/eb054500

Reynolds, J. (2002). Practical Guide to CRM: Building More Profitable Customer Relationships. CRC Press. https://doi.org/10.1201/9781482280784

Richards, K. A., \& Jones, E. (2008). Customer Relationship Management: Finding Value Drivers. Journal of Collaborative Customer Relationship Management, 37, 120-130. https://doi.org/10.1016/j.indmarman.2006.08.005

Rollins, M., \& Halinen, A. (2005). Customer Knowledge Management Competence: Towards a Theoretical Framework. Proceedings of the 38th Annual Hawaii International Conference on System Sciences, Big Island, 6 January 2005, 240a. https://doi.org/10.1109/HICSS.2005.180

Tetteh, A. V. (2008). Customer Relationship Management: A Research Starter Business. 